\author{
Thomas DaCosta Kaufmann
}

\title{
BALTIC REFLECTIONS
}

\section{OVERTURE}

Clouds float in the bright cerulean sky. The sun reflects off waves that beat on the rocks of the jagged coast. Houses dot a soft sand beach that rolls in a crescent for two miles. Marshes full of birds lie behind the dunes and breakers just behind the shore. Farms with fields line the road leading inland. Extensive forests of evergreens stretch out beyond them. They enclose many shaded lakes.

Some of these sights may be viewed from the house where part of this paper was conceived; others come from memories evoked there. But none are phenomena experienced in the Baltic area. All these experiences all originated in the summer light of the coast at Biddeford, in the state of Maine in the United States of America.

Maine is of course very far from the Baltic - well over 3600 miles. But many aspects of its physical geography certainly are comparable to what is found in the Baltic lands. Although I did not notice such similarities when I first visited Denmark with my family fifty-five years ago, much struck me during my first visit to Sweden forty years ago. I observed that Sweden resembled Maine, extended. Subsequently I have noticed many other parallels with what can be seen in the Baltic States, northeastern Germany, and northern Poland.

Cultural geography differs from physical geography, to be sure. Human traces have shaped the culture of the Baltic region differently from the Western Hemisphere for centuries, even millennia. Some of the manifold artistic and architectural manifestations of monuments and artifacts 
in the Baltic are discussed elsewhere in this volume. The long history of human habitation has left its mark on the Baltic lands with many objects which likely are not to be discovered outside of museums in the United States. However, with the museum of Bowdoin College the state of Maine in fact may boast of a collection whose origins date to the earlier eighteenth century in Europe.

Yet Maine also vaunts a lengthy cultural geography, if one obviously different from that of the Baltic area. Penobscot and Abenaki indigenous peoples have long inhabited the Maine coast and interior. They hold an annual powwow in Biddeford. Some of their settlements and trading centers found in excavations date to the age of the Vikings; undoubtedly they were present here long before that period. Moreover Maine's own artistic heritage is hardly negligible. At least from the nineteenth century painting in Maine can claim high status. Fitz Hugh Lane, Thomas Cole, Frederick Church, Winslow Homer, Marsden Hartley, and Andrew Wyeth are some of the important American artists who painted in Maine, Homer on the next promontory to Biddeford's at Prouts Neck. ${ }^{1}$

Connections also exist between the two areas. Viking seafarers came near the coasts of Maine. Clear evidence for their settlements has been uncovered on Newfoundland and Baffin Island in Canada. If the "Maine penny," a European coin supposedly found in a twelfth-century site near Blue Hill Maine, is accepted as evidence, the Vikings may even have traded with the indigenous peoples of Maine. Could they have landed there as well? In any case, centuries later, when cities like Kristianstad were founded in Scania, French and British founded towns and forts in Maine, too, in the first years of the seventeenth century. One example is Winter Harbor, now Biddeford Pool, located near the place where these reflections were inspired: it was settled in 1616-1617, a few years before the Pilgrims landed in Plymouth. Goods from Central Europe arrived in Maine, too, as they were with Scandinavia; a Rhenish ceramic vessel belonged to an eighteenth-century collection in Saco, the next town to Biddeford (it is to be seen in the Saco Museum). And many eighteenth-century houses, some quite grand, still exist in Kennebunk to the south and Saco to the north of Biddeford.

1 For some of these figures see: John Wilmerding, The Artist's Mount Desert. American Painters on the Maine Coast (Princeton: Princeton University Press, 1994). For Homer at Prout's Neck see: Philip C. Beam et al., Winslow Homer in the 1890's. Prout's Neck Observed (Rochester: Memorial Art Gallery, 1990). 
Suggesting comparisons and connections such as these may seem an idle exercise. But it serves to point out a practical problem with "poetic" or phenomenological approaches to history or geography. Our personal reactions may be suggestive, evocative, even enriching. They may seem to be creative and imaginative. Geographical features have no doubt inspired many artists and writers to create works, both in Maine and the Baltic region. But to say that geography directs the course of the creative imagination seems to be a questionable proposition whether it is applied to the Baltic or to Maine. ${ }^{2}$ Hence while evocative, and perhaps personally meaningful to the author, such comparisons should be granted no more weight than those that might be made with many other places. The comparison of the Baltic with Maine shows how such reactions can lead quite literally very far afield. Care should be taken with such approaches if they are not to slip into the realm of pure fantasy, diverging far from analysis of concrete historical and geographical realities. ${ }^{3}$

Such cautionary remarks seem to merit being made especially at the present moment. Poetic, phenomenological approaches no doubt have a place in the criticism of art and architecture, one that they have long enjoyed. And this sort of subjective observation may seem to be all the more valid with the wave of postmodernism in the history of art. There now exists a vogue for the anachronic (the revival of an old idea that art works may be related to multiple temporalities). ${ }^{4}$ The atopic might be a comparable notion in art geography, and thus seems to justify further making of any kind of geographical association which one wishes, just as what might have seemed to be "preposterous history" now allows all sorts of connections between vastly different time periods and contexts. ${ }^{5}$

To turn around the words of one of the advocates of the anachronic, the effort to ground historical and geographical approaches to art empirically is not just the result of a "rationalist fear of ideological mysti-

2 See my comments in this regard in Thomas DaCosta Kaufmann, Toward a Geography of Art (Chicago and London: University of Chicago Press, 2004), 101, referring to ibidem and a number of other works by the same author on American art.

3 These reactions were inspired by a response to Juhan Maiste, "The Glass Bead Game in the Topic of Classics. Baltic Identity and the Transport of Culture", Scandinavia Journal of History, XXVIII (2003), 273-383; Juhan Maiste, "Kadriorg: the Spirit of Baroque and the Will of Genius. A Palace on the Edge of the Third Rome", Baltic Journal of Art History, 6 (2013), 155-178.

4 See: Alexander Nagel and Christopher S. Wood, The Anachronic Renaissance (New York: Zone Books, 2010).

5 See: Mieke Bal, Quoting Caravaggio: Contemporary art, Preposterous history (Chicago and London: University of Chicago Press, 1999). 
fication." Rather, it represents the rejection of the resuscitation of appeals to irrationality and the promotion of erroneous arguments in the name "creative art history and cultural history," whatever that may mean. ${ }^{6}$ Be that as it may, even if we are prepared to abandon many aspects of anti-rational art history, ${ }^{7}$ whose consequences and anti-Kantian, anti-Enlightenment premises should now be more than clear, ${ }^{8}$ a rational, analytical standpoint does not provide more than a general outlook.

Specifically, it is not easy to propose a rational approach to subjects such as Baltic art geography (and history). A brief review of the historiography of the concept of the Baltic as a region may suggest some of the difficulties inherent in this project.

\section{HISTORIOGR APHIC CONCEPTS}

Kunstlandschaft, Artedominium, Kulturkreis, region, frontier, border zone - these are but some of the concepts that have been applied to the area of the Baltic Sea. The wealth of terms derives from a long history of discussions, which, as the present volume indicates, still continues to engage scholarship. Although its geography and history might seem relatively confined, the Baltic has consistently eluded a clear definition that commands consensus. Indeed, the Baltic has been both a point of origin and a testing ground for a wide variety of theories that have had greater purport for treatments of the geography and history of art.

At first, some basic facts of physical geography might seem to be indisputable. The Baltic Sea is an ocean in Northern Central Europe. It is 1600 kilometers long at its greatest extent, but still less than 200 kilometers across at its widest. Unlike the Mediterranean, with which it is sometimes compared, it has only one set of exit points, through the Danish straits. Hence it is not in general subject to great storms, unlike other oceans, and it is also not extremely deep. It shares a relatively similar climate all around its 8000 kilometer-long coastline.

6 See: Christopher S. Wood (ed.), The Vienna School Reader: Politics and Art Historical Method in the 1930s (New York: Zone Books, 2000), 46.

7 Ibidem.

8 Those who wish to resuscitate art historians like Hans Sedlmayr have to deal with the fact that he was not an opportunistic Nazi, but openly described himself as a "political" Anti-Semite. See: Evonne Levy, "Sedlmayr and Schapiro Correspond, 1930-1935", Wiener Jahrbuch für Kunstgeschichte, 59 (2010), 235-263. 
These physical factors have affected various aspects of human habitation in the region. Among other things, they have facilitated transport and communication across a common body of water. They might thus seem to establish equally indisputable foundations for a cultural geography of the Baltic.

In fact, basic physical factors have long provided the basis for considerations of the culture of the Baltic area in relation to its geography and climate. From the early modern period (late fifteenth through eighteenth century) onward, ideas of its cultural productions have related the lands of the Baltic region to such matters as the materials available for construction. ${ }^{9}$ At a time when the formal discourse of the history of art began to take shape in the late eighteenth century, Carl August Ehrensvärd further articulated geographical notions in relation to the distant location of Sweden and its climate, a common theme. ${ }^{10}$ As the academic discipline of art history was formed, in the nineteenth century, other such geographical notions were developed. This was of course a time when thinkers emphasized the importance of ethnic elements, often expressed as concepts of "Volk" or "Nation". Consequently racial, national, and especially significant for geographical concerns, regional explanations that had been implicit in earlier discussions became explicit in a more philosophically and ideologically driven discourse. ${ }^{11}$ These sorts of ideas were made manifest in the foundation of museums and other institutions. A prominent example is the Nordic Museum in Stockholm, which was founded as Scandinavian ethnographic collections, and was reshaped and renamed in an expression of a more patently clear ideology.

In the early twentieth century a newly self-defined geography of art took off from such foundations. Art geographical considerations introduced cartography and also theoretical reflections into a self-proclaimed geography of art. At this time several concepts that have been cited above were coined in relation to artistic geography. Most notably, notions of the Baltic were framed in relation to ideas of Kunstlandschaft, Artedominium, and the like. They culminated in the talks given at the

9 See: Thomas DaCosta Kaufmann, "Early Modern Ideas about Artistic Geography Related to the Baltic Region“, Scandinavian Journal of History, 28 (2003), 263-272.

10 See: Carl August Ehrensvärd, Resa til Italien och andra skrifter (Täby: Lind\&Co, 1999).

11 For a general discussion of these issues in the context of the development of the geography of art, see DaCosta Kaufmann, Toward a Geography of Art. 
International Congress of the History of Art, held in Stockholm in 1933. ${ }^{12}$ While the Second World War that broke out soon afterwards interrupted the debate, Jan Białostocki consciously revived the discussion in the 1970's, with an important paper on the Baltic area as an artistic region in the sixteenth century. ${ }^{13}$ Since then the topic has been treated productively by many other scholars, among them Jan von Bonsdorff. ${ }^{14}$ Several more contributors have entered the discussion, including the present author, and scholarship on related subjects has continued into the twenty-first century. ${ }^{15}$

Nevertheless many critiques have been directed at conceptions of the Baltic region in cultural or artistic geography. Von Bonsdorff has ably summarized them in several places. ${ }^{16}$ We may go further. The phenomenological overture to this essay may have suggested that not even basic descriptions, much less definitions, may seem to supply clear points of reference.

\section{BALTIC LIMITS}

How far does the Baltic Area extend? If instead of subjective reactions some objective criteria are applied like those suggested above, the most

12 For an excellent summary see Jan von Bonsdorff, „Kunstproduktion und Kunstverbreitung im Ostseeraum des Spätmittelalters“, Finska Fornminnsesföreniningens Tidskrift, 99 (1993), 13-21.

13 Jan Białostocki, “The Baltic Area as an Artistic Region in Sixteenth Century”, Hafnia: Copenhagen. Papers in the History of Art, 1976, 11-24.

14 See especially von Bonsdorff, „Kunstproduktion und Kunstverbreitung im Ostseeraum des Spätmittelalters"; "Global Aspects on [sic] Johnny Roosval's Concept of the Artedominium”, Crossing Cultures: Conflict, Migration and Convergence (Acts of the 32nd Congress of the International Committee of the History of Art), ed. by Jaynie Anderson (Melbourne: University of Melbourne Press, 2009), 86-90. 15 Thomas DaCosta Kaufmann, "Påverkan västerifrån: nederlänsk konst och arkitektur", Gränsländer. Östersjön in ny gestalt, ed. by Janis Kreslins, Steven A. Mansbach, Robert Schweitzer (Stockholm: Atlantis, 2003), 17-41 (also published as "Makslinieciska attesteba: vizuani maksla baltijas vestur", Baltija: jauns skatjums (Riga: Aténa, 2003), 241-60); "Early Modern Ideas about Artistic Geography Related to the Baltic Region”, Scandinavian Journal of History, 28 (2003), 263-272 (published 2004); "Das Ostseeraum als Kunstregion: Historiographie, Stand der Forschung, und Perspektiven künftiger Forschung", Land und Meer. Kultureller /Austausch zwischen Westeuropa und dem Ostseeraum in der Frühen Neuzeit, ed. by Martin Krieger, Michael North (Cologne, Weimar, Vienna: Böhlau, 2004), 9-21; "The Baltic Area as an Artistic Region. Historiography, State of Research, Perspectives for Further Study", Po obu stronach Bałtyku/On the Opposite Sides of the Baltic Sea, ed. by Jan Harasimowicz, Piotr Oszczanowski, Marcin Wislocki (Wrocław: Via Nova, 2006), 33-39; "Ways of Transfer of Netherlandish Art”, Netherlandish Artists in Gdańsk in the Time of Hans Vredeman de Vries (Gdańsk: Museum of the History of the City of Gdańsk, 2006), 13-22; "Art and the Church in the Early Modern Era: The Baltic in Comparative Perspective", Art and the Church/ Kunst und Kirche. Religious Art and Architecture in the Baltic Region in the 13th-18th Centuries/Kirchliche Kunst und Architektur in der baltischen Region im 13.18. Jahrhundert, ed. by Krista Kodres, Merike Kurisoo (Tallinn: Eesti Kunstiakadeemia, 2008), 20-40.

16 Białostocki, “The Baltic Area as an Artistic Region in Sixteenth Century”, 11-24. 
basic question of the definition of limits might at first seem to be clear. As suggested, physical geography appears to provide a clear definition whereby the Danish straits leading to the Kattegat mark the end point of the Baltic. The physical geography of the Baltic seems clearly contained, and so does its cultural geography. Nevertheless, this apparently straightforward application of a definition from physical geography has long proved insufficient for the conception of the Baltic as a region of cultural geography.

Scholarship has long been troubled with the relation of Scandinavia related to the Baltic region. ${ }^{17}$ Much of Sweden and all of Norway have simply no coast on the Baltic Sea. And where on the other hand does the southern border of this region lie? Mecklenburg is included in many accounts, such as that of Białostocki. In Mecklenburg Wismar is accessible to the Baltic, and Schwerin, and Güstrow, another ducal residence does not lie far away from the coast. But is Ludwigslust a Baltic city to be brought into account along with Lübeck?

The Baltic region seems to be quite porous. This is not merely because, as has often been stated, the Baltic is a region to which culture has been transferred from outside. This explanation has further implications. Kristoffer Neville's arguments imply that the Baltic is not merely two-sided, as one well known compendium has suggested. ${ }^{18}$ He posits that its art and architecture may be considered part of a greater region of Central Europe, collapsing this distinction. ${ }^{19}$ The Baltic region may also be associated with several other regions. Denmark, Norway, and some of the Germanic parts of the Baltic area have been linked with other lands as constituting a distinctive region of cultural geography around the North Sea. ${ }^{20}$ This is part of the reason why in the historiography of the Baltic as a geographical region other notions related to culture such as that of a Kulturkreis replaced descriptions based on simple physical facts.

17 See: Kristoffer Neville, "Scandinavia and the Baltic", Atlas of World Art, ed. by John Onians (Oxford: Oxford University Press, 2004), 156-157.

18 See: Po obu stronach Bałtyku/On the Opposite Sides of the Baltic Sea, ed. by Jan Harasimowicz, Piotr Oszczanowski, Marcin Wislocki (Wrocław: Via Nova, 2006), 33-39.

19 See: Kristoffer Neville, Nicodemus Tessin the Elder. Architecture in Sweden in the Age of Greatness (Turnhout: Brepols, 2010).

20 For attempts to "map" the cultural geography of this region see in The North Sea and Culture (1500-1800), ed. by Juliette Roding, Lex Heema van Voss (Hilversum: Verloren, 1996). 


\section{BALTIC EXTENSIONS}

This apparent conundrum of determining how the area's physical location may be related to its definition as a cultural region however leads to possible solutions suggested by its very relationship with several distinctive artistic/cultural regions. The Baltic might be defined in a broader sense as peripheral - in relation to Central Europe and to Western or Eastern Europe for that matter. Its lands lie outside of or are marginal to many parts of Europe. But the notion of periphery implies a center to which the Baltic might be considered to be peripheral. Moreover, if the Baltic is treated as peripheral, it is peripheral to several areas and centers. The idea that the Baltic region is peripheral becomes quite clear even if we regard the Baltic, as I have elsewhere suggested, as representing a region in which "cultural transfer affects artistic monuments within the longue durée of a distinctive geography of art.".21

The terms of this discussion suggest that art and culture are transferred not only from the Low Countries, but from Italy, and from other places in Germany, as has often been suggested. In this framework, there does not exist any single center, but several centers to which the Baltic may be related. However, thinking in terms of multiple centers and relations explodes a simple paradigm of single centers and peripheries. And where, as the notion of the definition of a region which is to be related to a center implies, would the Baltic's own center be located? At any given time several places may be chosen as contenders for this title.

The farther the range of references is extended, the more difficult it also becomes to retain a simple center-periphery model. Denmark, and for a while Sweden, had empires that expanded outside of Europe. Again pointing out the multiple centers within the Baltic, as these occurred more or less simultaneously for a while during the seventeenth century, Denmark controlled and colonized Greenland (technically in the Americas), the Virgin Islands, Tranquebar and elsewhere in India, and forts along the gold coast of Africa. Sweden briefly colonized New Sweden in the states of Delaware, Pennsylvania, and New Jersey in the United States; held St. Barthelemy in the Caribbean; and controlled some spots for the slave trade in Africa. Chinese export paintings of the Hongs of Canton (Guangzhou) also show the flags of both nations fly-

21 DaCosta Kaufmann, "Art and the Church in the Early Modern Era: The Baltic in Comparative Perspective", 40. 
ing over factories (trading posts) there. And if Russia is included with the Baltic, to which it gained a foothold at various times and where it now holds part of what used to be Prussia, then the Russian expansion in Asia may also be noted. From a global perspective centers abound, and they are located within the Baltic itself, or countries within it. Yet these centers are multiple.

\section{BALTIC LIMINALITY AND FRONTIERS}

Rather than considering the Baltic lands as peripheral, a more helpful notion might be the liminal. In addition to problems already noted, periphery implies the relation of a center to a periphery, in which the center is always implicitly dominant. The periphery is merely receptive, not productive. This is a problem with the notion of cultural transfer, that it regards the Baltic merely as a recipient of such transfer, not its sources. Liminality also suggests the border or edge of a space, but the edge may not be that of just one area or zone, but between two or more zones. This is evoked in the notion of Baltic borderlands. Nor does being liminal necessarily imply any sort of hierarchy. ${ }^{22}$ Liminality thus surpasses the older, more conventional notion of periphery, even if the peripheral is regarded as having certain advantages for the possibilities of cultural innovation. ${ }^{23}$

Liminality also may be related to another notion, that of frontiers. The recently deceased Italian art historian Enrico Castelnuovo suggests the possibility of a doubled geographical impact. Frontiers may be envisioned as suggesting sites where cultures meet and contact. Such encounters may also spark creative reactions in various forms of cultural production. ${ }^{24}$

Some of the implications of the idea of considering frontiers as contact zones between two cultures or lands can easily be applied to the histo-

22 Thomas DaCosta Kaufmann, "Reframing the Frames: The European Perspective", Reframing the Danish Renaissance. Problems and Prospects in a European Perspective. Papers from an International Conference in Copenhagen 28 September - 1 October 2006, ed. by Michael Andersen, Birgitte Bøggild Johannsen, Hugo Johannsen, Publications of the National Museum Studies in Archaeology and History, 33, (2011), 32-50.

23 As by Jan Białostocki, "Some Values of Artistic Periphery", World Art: themes of Unity and Diversity, ed. by Irving Lavin et al. (University Park, Pennsylvania: Pennsylvania State University Press, 1989), 49-58.

24 See the essays reprinted in Enrico Castelnuovo, La cattedrale tascabile. Scritti sulla dell'arte (Lvorno: Sillabe, 2000). 
ry and geography of art of the Baltic region, however hazy its physical geographical dimensions may be. ${ }^{25}$ The liminal position of the Baltic between several different cultural geographical zones may be considered both as a descriptive category, and as a cultural catalyst. Furthermore, the very fact that it may be related to various sorts of frontiers may help define the Baltic as a cultural region.

First, as is most clearly seen perhaps in northern Poland, the Baltic is a place not only to be regarded as a region to which northern and southern artistic streams flow. Netherlandish and Germanic masons, sculptors, painters, and goldsmiths all created or provided works for the cities of the littoral zone. But Italian artists passed through the region too, or sent objects here. While the Baltic in some senses may have been a Netherlandish lake, it also did not impede the passage of figures like the Parr to Kalmar in southeastern Sweden, for instance. Hence these qualities may often be seen in different modalities being executed by artists and artisans of different origins. And they also may overlap.

The liminal nature of artistic production also suggests another way of regarding styles or ornaments and architecture. The supposed stylistic progression envisioned by art historians does not ever correspond to the actual contemporaneity of styles which supposedly represent different epochs. Without reference to the "anachronic," art historians emphasize the coexistence of supposedly different styles, even in the same work at the same time. ${ }^{26}$ More pronouncedly, a variety of works created at the same time in forms that recall the Gothic, Netherlandish Mannerism, or the Italian Renaissance is found in places like Danzig/Gdańsk, Riga, and Vilnius. At a later moment forms that recall the classicism of northern Palladianism coexist with supposedly baroque monuments, notably in Vilnius and Riga.

These apparent visual differences may be compared to (if not regarded as the expression of) other sorts of cultural differences. The Baltic is also a place where long into the Late Middle Ages Christian and "pagan", then western Christian and Orthodox, later Catholic and Protestant, met, often in conflict. Orthodoxy is represented by Russia, which historical-

25 I owe some of these ideas to the stimulus of Ojārs Spāritis. See further for this notion in a more negative sense in Shatterzone of Empires: Coexistence and Violence in the German, Habsburg, Russian, and Ottoman Borderlands, ed. by Omer Bartov, Eric D. Weitz (Bloomington: Indian University Press, 2013).

26 See: Ethan Matt Kavaler, Renaissance Gothic: Architecture and the Arts in Northern Europe, 14701540 (New Haven, Ct., London: Yale University Press, 2012). 
ly (beyond the post-1945 Russian seizure of part of Prussia) has a stake in the region, as seen in St. Petersburg and environs. Orthodox buildings may be seen in many of the lands outside of Russia, where they were built when Russia dominated the area, in Vilnius, Riga, and perhaps most conspicuously in Tallinn. Recent events clearly indicate the revival of a Kulturfälle between orthodoxy and Russia and the rest, too.

Other divisions might be multiplied. They could relate to patterns of patronage supplied by the royal (or ducal) courts on the one hand (Denmark, Sweden, Gottorp (Gottorf), Ducal later Royal Prussia) versus separate, even free cities (Gdańsk, Wismar, in the latter category Lübeck and Hamburg). Many other notions, of ethnicities, languages, materials, markets, might also be brought to bear.

\section{ENVOI}

Given the open-ended nature of ongoing considerations, and the effort to provoke reconsideration here, no pat conclusion is possible. No single, simple definition of the Baltic, including the descriptions previously offered, seems both to fit and to encompass the variety of phenomena found here. But another description that takes off from the notion of frontiers, and relates it to Kulturkreis, might in the end be helpful. Rather than one simple area or region, even one that varies in dimensions and times, the Baltic might be considered as region that consists in the intersection of several circles, whose borders are suggested by frontiers. This notion may be pictured as in a Venn Diagram from mathematical set theory. In a Venn diagram overlapping circles represent all the logical relations of finite sets. The area contained within the various circles of relationships, within the frontiers, their place of intersection, might symbolize the multiple relations of the Baltic region, and thereby help us to conceptualize how the otherwise seemingly disparate notion of the Baltic might be visualized as containing several distinctive sets of relationships. 
Thomas Dacosta Kaufmann: Baltic Reflections

Keywords: Anachronic (Critique Of) Baltic; Physical And Cultural Geography Of Liminality And Frontier Zones; Intersection Of Regions

SUMMARY:

There is no simple definition of the Baltic. Previous attempts to use the criteria derived from considerations of physical or cultural geography have not proved full adequate. This does not mean that there should be recourse to the dubious idea of the anachronic, or its equivalent, the "atopic". Rather than being regarded as liminal or a frontier zone in relation to other cultural or geographical regions, the Baltic might be conceived as representing their intersection.

CV:

Thomas DaCosta Kaufmann is Frederick Marquand Professor of Art and Archaeology. A member of the Royal Flemish, Royal Swedish, and Polish academies of sciences, he has been awarded the Palacký medal by the Czech Academy of Sciences and honorary doctorates from the Technical University, Dresden and the Masaryk University, Brno. He is the author of thirteen books that have been translated into a variety of languages, the chief editor of four, and also of well over 200 articles and reviews. 